\title{
Editors' Report 2017
}

\section{Editorial Changes}

At the beginning of 2017, Efrem Castelnuovo commenced as the Forum Editor, John Haisken-DeNew as Data Survey Editor and Jenny Lye as Editor of the For the Student section. Chris Ryan relinquished his position as a Co-Editor at the end of the year. His replacement is Nicholas Hérault.

After 34 years of exemplary service as Assistant Editor, Nellie Lentini has left the Melbourne Institute. During a period of great change, Nellie shepherded through 135 issues of the Review. The journal moved from being produced and distributed from within the Melbourne Institute to being produced and distributed by an international publisher. Readership moved from hard copy to online and became more international. The new Assistant Editor is Rosie Duffy.

This is the author manuscript accepted for publication and has undergone full peer review but has not been through the copyediting, typesetting, pagination and proofreading process, which may lead to differences between this version and the Version of Record. Please cite this article as doi:10.1111/aere.12274 


\section{Articles and Submissions}

The Review's established format of invited articles, contributed articles, a policy forum, a data survey and a section 'For the Student' were continued in 2017. Readership continues to grow, especially in Asia. Annual full-text downloads exceed 80,000 for the first time, with 40 per cent from overseas.

A summary of the composition of the articles published in the Review over the past 3 years is given in Table 1. Table 2 provides information on the number of articles received and their disposition. Submissions to the Contributed Articles section increased by 30 per cent to 76 in 2017. The increase was not matched by acceptance rates as more submissions were received from overseas authors and these were often too narrow in focus for the Review. While we welcome submissions from international authors, it is our intention that the Review remain a policy-oriented journal with particular relevance to Australia and the Asia-Pacific region.

Submissions that are outside the aims of the journal or clearly do not meet the required standard are rejected by the editors without going to referees. In this way authors get a quick response to unsuitable articles and referees are spared unnecessary work. Over the period 2015-2017 the acceptance rate was 21 per cent, but the acceptance rate for articles that went to referees was 50 per cent.

As befits a policy-oriented journal, we aim to keep the time between acceptance of articles and final publication in an issue of the journal to around 6 months. The current backlog of accepted articles awaiting publication represents two issues.

\section{Referees}

At least two referees are used for submissions of contributed articles that proceed to the refereeing process. We also use referees for the other sections of the journal. The integrity of the system of peer review is crucially dependent on the work of our referees. Editors of Australian journals continue to press for greater recognition of refereeing and editorial work by universities and the Australian Research Council in its Excellence in Research for Australia exercise. In another, unrelated initiative, the international website $<w w w . p u b l o n s . c o m>$ has been established to give recognition to the work of referees.

We thank our referees warmly for their contributions in providing a large number of constructive comments, both to the authors and the editors. The referees in 2017 were Peter Abelson, Charmele Ayadurai, Hazel Bateman, James Binkley, Nicole Black, Petri Bockerman, Barbara Broadway, James Broughel, Paul Burke, Lixin Cai, Arpita Chatterjee, Kevin Davis, Leo Dobes, John Freebairn, Jane Friesen, Jim Forrest, Ross Guest, Nicolas Herault, Paul Jensen, Hsein Kew, Jae Kim, Geoffrey Kingston, Thai-Ha Le, Tim Maloney, Artura Martinez Jr, Philip Maxwell, Lyndon Moore, Carsten Murawski, Athula Naranpanawa, Patrick Nolan, Glenn Otto, Martin Ploedt, Abdul 
Qayyum, Rasika Ranasinghe, Ranjan Ray, Christine Richmond, Mariano Rojas, Saroja Selvanathan, Anurag Sharma, Gerasimos Soldatos, Niger Stapledon, Dinh-Thanh Su, Aaron Tan, Roger Wilkins, Barry Williams, Lei Xu, Jing Zhao, and Rong Zhu

\section{Further Acknowledgements}

Abbey Treloar and Sheri Carnegie have provided excellent administrative assistance during the year. Finally, we wish to thank the team at our publisher, Wiley.

Ross Williams (Managing Editor)

Ian McDonald (Co-Editor)

Chris Ryan (Co-Editor)

March 2018

Table 1 Published Articles, 2015-2017

\begin{tabular}{lrrr}
\hline Type of article & 2015 & 2016 & 2017 \\
\hline Invited Article & 2 & 3 & 3 \\
Contributed Article & 15 & 14 & 13 \\
Policy Forum & 21 & 18 & 21 \\
Data Survey & 4 & 4 & 3 \\
For the Student & 4 & 4 & 4 \\
& & & \\
Number of pages & 452 & 524 & 500 \\
\hline
\end{tabular}


Table 2 Outcomes of Submissions of Contributed Articles, 2015-2017

\begin{tabular}{lrrr}
\hline Contributed articles & 2015 & 2016 & 2017 \\
\hline $\begin{array}{l}\text { Brought forward from the } \\
\text { previous year }\end{array}$ & 23 & 16 & 17 \\
New submissions during the & 52 & 58 & 76 \\
year & 75 & 74 & 93 \\
Total & & & \\
& & & \\
Decisions made & 14 & 14 & 13 \\
$\quad$ Published & 7 & 7 & 5 \\
$\quad$ Accepted: awaiting publication & 45 & 43 & 66 \\
Rejected/withdrawn & 6 & 6 & 4 \\
$\quad$ Awaiting revision & 3 & 4 & 5 \\
In process & 75 & 74 & 93 \\
Total & & & \\
\hline
\end{tabular}

This article is protected by copyright. All rights reserved. 


\section{University Library}

\section{- M M I E E R VA A gateway to Melbourne's research publications}

Minerva Access is the Institutional Repository of The University of Melbourne

Author/s:

Williams, R;McDonald, I;Ryan, C

Title:

Editors' Report 2017

Date:

2018-06-01

Citation:

Williams, R., McDonald, I. \& Ryan, C. (2018). Editors' Report 2017. Australian Economic Review, 51 (2), pp.301-302. https://doi.org/10.1111/1467-8462.12274.

Persistent Link:

http://hdl.handle.net/11343/284057 